\title{
DIFFERENT SHADING INTENSITIES INTERFERE WITH THE GROWTH OF Myrocarpus frondosus ALLEMÃO SEEDLINGS IN THE NURSERY?
}

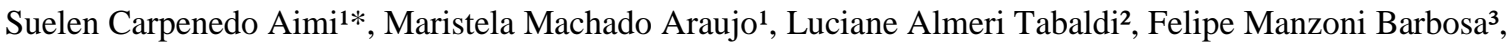 \\ Marllos Santos de Lima ${ }^{1}$, Claudia Costella ${ }^{1}$ \\ 1*Federal University of Santa Maria, Department of Forest Sciences, Santa Maria, Rio Grande do Sul, Brazil - e-mail: suaimi@gmail.com \\ araujo.maristela@gmail.com; marllos_lima@ hotmail.com; claudiacostella@ hotmail.com \\ ${ }^{2}$ Federal University of Santa Maria, Department of Biology, Santa Maria, Rio Grande do Sul, Brazil - lutabaldi @ yahoo.com.br \\ ${ }^{3}$ Federal University of Paraná, Department of Forest Science, Curitiba, Paraná, Brazil - felipemanzonibarbosa @ hotmail.com
}

Received for publication: 21/06/2019 - Accepted for publication03/10/2019

\begin{abstract}
Resumo
Diferentes intensidades de sombreamento interferem no crescimento de mudas de Myrocarpus frondosus allemão no viveiro? As espécies arbóreas apresentam respostas diferentes em relação a sua capacidade de adaptação e exigência a disponibilidade de luz. Assim, o objetivo desse estudo foi avaliar o crescimento de mudas de Myrocarpus frondosus sob diferentes sombreamentos, em viveiro. Foi utilizado o delineamento experimental blocos ao acaso em esquema fatorial, correspondendo a intensidade de sombreamento ( $0,30,50$ e 70\%) e aos tempos de avaliações (30, 90, 150, 210, 270, 330 e 390 dias após a emergência - d.a.e.). As avaliações dos atributos morfológicos altura $(\mathrm{H})$ e diâmetro do coleto (DC), para obtenção da relação H/DC, foram realizadas a cada 60 dias. Aos 390 d.a.e. foram avaliados os atributos matéria seca aérea, matéria seca radicular, matéria seca total, índice de qualidade de Dickson, área foliar, volume radicular e comprimento radicular, e os teores de pigmentos da clorofila $a$ e $b$, relação clorofila $a / b$, carotenoides, rendimento quântico máximo e taxa de transporte de elétrons. Myrocarpus frondosus necessita de sombreamento na fase inicial de seu crescimento, sendo o sombreamento de 50 e $70 \%$ uma alternativa adequada para produção das mudas. Palavras-chave: Fabaceae, Cabreúva, produção de mudas, atributos morfológicos e fisiológicos.
\end{abstract}

\section{Abstract}

Native tree species present different responses depending on their adaptability to varying degrees of sunlight. The objective of this study was to evaluate the growth of Myrocarpus frondosus seedlings under different shade conditions in a nursery. The experimental design included randomized blocks in a factorial scheme, corresponding to treatments of full sun $(0 \%)$, or one of three shading intensities $(30 \%, 50 \%$, and $70 \%)$, with evaluation times of $30,90,150,210,270,330$, and 390 days after emergence - d.a.e. The evaluation of the morphological attributes height $(\mathrm{H})$ and stem diameter (SD) were determined every 60 days, and H/SD ratio were calculated. At 390 d.a.e, the following attributes were evaluated: aerial dry matter, (ADM), root dry matter (RDM), total dry matter, (TDM), Dickson quality index (DQI), leaf area (LA), root volume (RV), and root length. The pigment contents of chlorophyll $a$, chlorophyll $b$, and chlorophyll $a / b$ ratio were also identified, along with carotenoid content, maximum quantum yield PSII $\left(\mathrm{F}_{\mathrm{v}} / \mathrm{F}_{\mathrm{m}}\right)$, and electron transport rate (ETR). Myrocarpus frondosus requires shading in its initial stage of growth, at an ideal intensity of $50 \%$ or $70 \%$ for producing seedlings.

Keywords: Fabaceae, cabreúva, seedling production, morphological and physiological attributes.

\section{INTRODUCTION}

The intense exploitation of natural resources, along with agricultural and urban center expansion has caused the deforestation of large native forest areas, reducing resources and biodiversity (STEFFEN et al., 2015; BRANCALION; CHAZDON, 2017). As a result, interest in the recovery and conservation of these areas has escalated, causing an increase in the demand for seedlings of native species, intended for projects to recover altered areas and commercial plantations, and the use of quality seedlings is fundamental for the success of these plantations (ARAUJO et al., 2018).

For the production of seedlings in forest nurseries, the demand for light must be considered, as tree species present different responses to varying intensities of light. The efficiency of energy conversion, production of carbohydrates, and growth of a species is causally linked to its ability to adapt to different lighting conditions (TAIZ et al., 2017). In addition, the intensity of shading can cause physiological, biochemical, and anatomical changes (SANCHES et al., 2017) in individuals.

Seedling quality is assessed by morphological attributes such as height $(\mathrm{H})$, stem diameter (SD), H/SD ratio, leaf area, root length, aerial matter, root matter, total dry matter, and Dickson quality index. Although these attributes present important information about the quality of the plants, they are considered incomplete (ARAUJO

FLORESTA, Curitiba, PR, v. 51, n. 1, p. 137-145, jan/mar 2021.

Aimi, S. C. et.al.

ISSN eletrônico 1982-4688

DOI: $10.5380 /$ rf.v51 i1. 67548 
et al., 2018). According to the same authors, physiological attributes such as chlorophyll $a$ fluorescence and photosynthetic pigments can also be used to determine the quality of plants produced in the nursery.

An increase in chlorophyll $b$ is an important characteristic in plants in shaded environments, because this compound captures energy from other wavelengths and transfers it to chlorophyll $a$, which effectively acts in the photochemical reaction of photosynthesis, representing a mechanism of adaptation to the reduction of light intensity (LARCHER, 2000). The study of luminosity, particularly the plasticity of species under different lighting conditions, provides information on the relationship between light intensity and the morphological and physiological attributes of plants, as well as on the production of seedlings, and allows for the evaluation of potential projects to recover altered areas and commercial plantations.

Some species of the Fabaceae family, such as Hymenaea courbaril L., Enterolobium contortisiliquum (Vell.) Morong (LIMA et al., 2010), and Copaifera langsdorffii Desf. (REIS et al. 2016), showed satisfactory growth under shade. From these studies, it is determined that the demand for light can favor or hinder the initial development and the morphological and physiological quality of the seedlings in the nursery.

Studies on the adaptation of tree species to the availability of light in their growing environment contribute to our knowledge of the management of seedlings in nurseries, and provide us with field planting techniques, as is the case with Myrocarpus frondosus (cabreúva) (Fabaceae) that occurs naturally in Bolivia, Paraguay, and Brazil (MISSOURI BOTANICAL GARDEN, 2019). This species is deciduous and classified as early (GRINGS; BRACK, 2009) to late-secondary. In addition, Carvalho (2003) described it as a semi-heliophile species that tolerates medium-intensity shading. It has very resistant and dense wood ( 870 to $\left.1,002 \mathrm{~kg} \mathrm{~m}^{-3}\right)$, which is used for ecological, landscape and medicinal purposes, and is also involved in the reconstruction of altered ecosystems and riparian forests. This species is also utilized in the perfumery and dye industries (CARVALHO, 2003; SANTI et al., 2017).

The growth of native tree species depends on their ability to adapt to the luminous conditions of their specific environment (LIMA et al., 2010; REIS et al., 2016). The use of these species in programs for the recovery and conservation of habitat requires information on the demand for luminosity, in order to successfully establish seedlings in the field. In this sense, we sought to verify the following hypothesis: different levels of shading ( $0 \%$, $30 \%, 50 \%$, and $70 \%$ ) can interfere with the growth, and morphological and physiological quality of Myrocarpus frondosus seedlings in a nursery. Thus, the objective of this study was to evaluate the growth of cabreúva seedlings under different levels of shading.

\section{MATERIAL AND METHODS}

The experiment began in April 2015 and was conducted until May 2016 at Viveiro Florestal (29 43' 13"

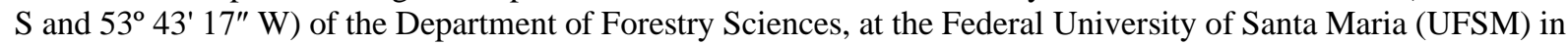
Santa Maria, RS. According to the Köppen classification, the region's climate is subtropical, of the "Cfa" type, with average temperatures in the coldest month of $-3{ }^{\circ} \mathrm{C}$, the warmest above $22{ }^{\circ} \mathrm{C}$, and annual average precipitation of 1,620 mm (ALVARES et al., 2013).

The meteorological data of precipitation, and average, maximum, and minimum temperatures recorded in the municipality of Santa Maria during the experiment were obtained from the Meteorological Station of Santa Maria, located on the UFSM Campus (Figure 1).

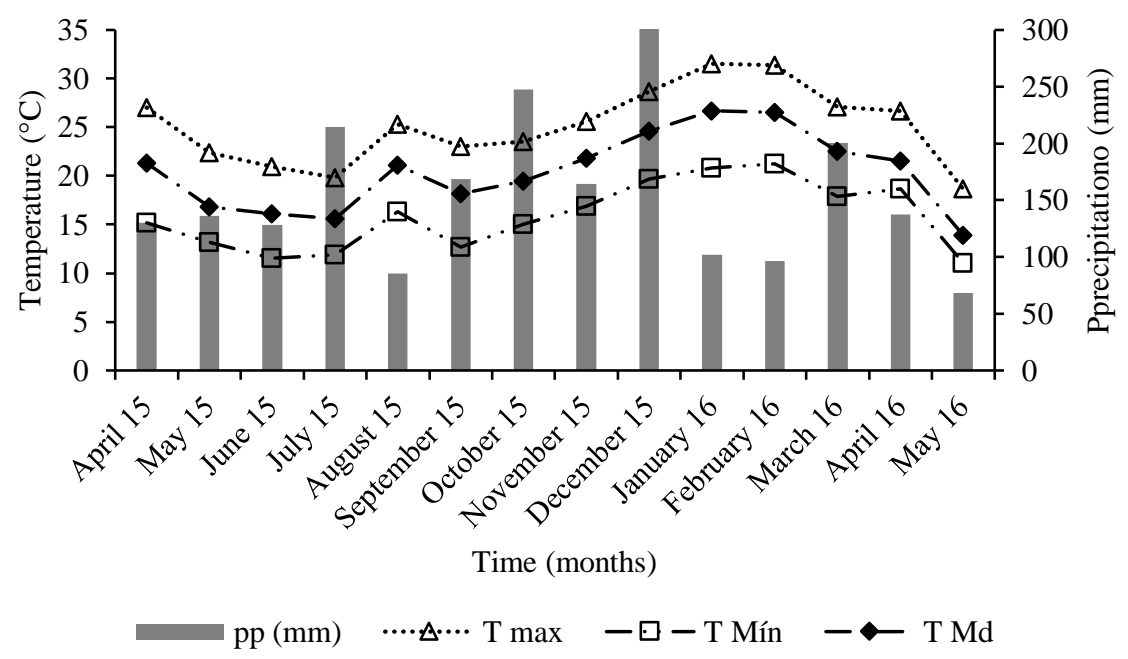

FLORESTA, Curitiba, PR, v. 51, n. 1, p. 137-145, jan/mar 2021.

Aimi, S. C. et.al.

ISSN eletrônico 1982-4688

DOI: $10.5380 /$ rf.v51 i1. 67548 
Figure 1. Precipitation (pp), maximum temperature (T Max), minimum temperature (T Min) and average monthly temperature ( $\mathrm{T} \mathrm{Md}$ ) registered by the municipality of Santa Maria, RS, during the conduction of the experiment in the nursery.

Figura 1. Precipitação (pp), temperatura máxima (T Max), temperatura mínima (T Min) e temperatura média mensal (T Md) registradas no município de Santa Maria, RS, durante a condução do experimento no viveiro.

The diaspores of Myrocarpus frondosus were collected from forest fragments of 12 parent trees in December 2014, in the municipality of Nova Palma, RS ( $29^{\circ} 28^{\prime} 25.09^{\prime \prime} \mathrm{S}$ and 53 $17^{\prime} 50.8^{\prime \prime} \mathrm{W}$ ). After collection, the diaspores were taken to the Forest Nursery and stored in a dry and cold room $\left(18{ }^{\circ} \mathrm{C}\right.$ and $49 \%$ relative humidity).

The containers used in the production of the seedlings were polypropylene tubes with a volume of 180 $\mathrm{cm}^{3}$ (50.72 $\mathrm{mm}$ in upper diameter; $13.5 \mathrm{~cm}$ in height and 8 internal friezes). The tubes were placed in $62.0 \mathrm{~cm}$ long polypropylene trays that were $42.0 \mathrm{~cm}$ wide and $16.0 \mathrm{~cm}$ high, with a capacity of 54 containers. The commercial substrate, Carolina Soil® (based on Sphagnum peat, expanded vermiculite, dolomitic limestone, and agricultural plaster), was used to produce the seedlings, along with base fertilization by $8 \mathrm{~g} \mathrm{~L}^{-1}$ of controlled release fertilizer, Osmocote ${ }^{\circledR}$ Mini Prill, in the formulation of 18-05-09 $\left(\mathrm{N}-\mathrm{P}_{2} \mathrm{O}_{5}-\mathrm{K}_{2} \mathrm{O}\right)$. According to the manufacturer's technical specifications, when placed on a humid substrate, at an average temperature of $21{ }^{\circ} \mathrm{C}$, the release of all nutrients occurs between six and eight months.

Sowing was carried out in April 2015 using two diaspores per container. After sowing, the trays were placed in a greenhouse where they remained for 30 days until emergence, after thinning and alternating, and the trays were taken to the growing area. The experimental design used was five randomized blocks in a $4 \times 7$ factorial scheme (shading $\times$ time) with plots subdivided over time. The shading intensities were $0 \%$ (full sun), $30 \%, 50 \%$ and $70 \%$, and the height and diameter measurements of the collection were performed at 30, 90, 150, 210, 270, 330, and 390 days after emergence (d.a.e.). Nylon shading screens were used, arranged over PVC pipe structures, forming shading clamps. After seven months, top dressing was started with a solution prepared by dissolving 200 $\mathrm{g}$ of ammonium sulfate and $150 \mathrm{~g}$ of potassium chloride in $100 \mathrm{~L}$ of water, as recommended by Gonçalves et al. (2005). The application was carried out every ten days until the end of the experiment, with the presence and absence of potassium chloride in the solution, by watering in the first hours of the morning.

The morphological attributes height $(\mathrm{H})$ and stem diameter (SD) were evaluated at 30, 90, 150, 210, 270, 330 , and 390 d.a.e., and the H/SD ratio was obtained. $\mathrm{H}$ was measured with a ruler $(\mathrm{cm})$ and SD with a digital caliper (mm), using eight central plants in each treatment, in five blocks. At 390 d.a.e., destructive evaluations were carried out on four seedlings per block of each treatment to obtain the leaf area (LA), root volume (RV), root length (RL), aerial dry matter (ADM), root dry matter (RDM), dry matter total (DMT), and Dickson quality index (DQI) (DICKSON et al., 1960).

The seedlings were separated into aerial parts and roots, and the root system was washed in running water and sieved $(0.84 \mathrm{~mm}$ mesh). For the leaf area and root length, the leaves and roots were distributed on A4 white paper, pressed by glass, and photographed using a SONY digital camera (model DSC-T100), with 1.4 times zoom, supported on a fixed height structure of $0.18 \mathrm{~m}$. The images were processed in the Image $\mathrm{J}$ program to obtain the leaf area and root length. The volume of roots was obtained by placing them in a graduated cylinder containing a known amount of water and measuring the change in volume. Subsequently, the aerial and root samples were placed in brown paper packaging, tagged, and taken to a greenhouse with forced air circulation at $65^{\circ} \mathrm{C}$, where they were maintained until they reached a constant weight for $72 \mathrm{~h}$, at which time the samples were weighed on a precision analytical balance $(0.001 \mathrm{~g})$ to obtain dry matter.

In addition to the morphological attributes, the physiological attributes of chlorophyll $a$ fluorescence and photosynthetic pigments were evaluated. To determine the characteristics of the photosynthetic pigments chlorophyll $a, b$ and carotenoids, the fourth expanded leaf of five seedlings per treatment was collected. The samples had previously been frozen in liquid nitrogen and stored in an ultra-freezer at $-80{ }^{\circ} \mathrm{C}$ until the time of quantification, which was performed at Plant Physiology Laboratory of the Biology Department of UFSM. According to the methodology of Hiscox and Israelstam (1979), fresh leaf samples $(0.05 \mathrm{~g})$ were incubated at 65 ${ }^{\circ} \mathrm{C}$ for $2 \mathrm{~h}$ with dimethyl sulfoxide (DMSO), and the absorbances were read on a spectrophotometer (Celm E205D ), at wavelengths of 663, 645, and $470 \mathrm{~nm}$ for chlorophyll $a$, chlorophyll $b$, and carotenoids, respectively. After the readings, the averages were estimated using the Lichtenthaler formula (1987).

The fluorescence of chlorophyll $a$ was measured in five plants per treatment, using a Junior-Pam portable modulated light fluorometer (Walz, Germany). The measurement was performed between 7:30 am and 10:30 am, on sunny days with no clouds, using the expanded leaves located in the middle third of the plant. The leaves were

FLORESTA, Curitiba, PR, v. 51, n. 1, p. 137-145, jan/mar 2021.

Aimi, S. C. et.al.

ISSN eletrônico 1982-4688

DOI: $10.5380 /$ rf.v51 i1. 67548 
adapted to the dark for 30 min to evaluate the maximum quantum yield PSII $\left(\mathrm{F}_{\mathrm{v}} / \mathrm{F}_{\mathrm{m}}\right)$, obtained by means of the variable fluorescence ratio $\left(\mathrm{F}_{\mathrm{v}}=\mathrm{F}_{\mathrm{m}}-\mathrm{F}_{\mathrm{o}}\right)$ and the electron transport rate (ETR).

The data were evaluated for the assumptions of normality of residues and homogeneity of variance using the Shapiro-Wilk and Bartlett tests, respectively, with the aid of the Action supplement (Equipe Estatcamp, 2014). When a significant difference was observed between treatments by the $\mathrm{F}$ test, the means were compared using the Tukey test and/or polynomial regression $(\mathrm{p}<0.05)$. The Sisvar v. 5.3 package (FERREIRA, 2014) was used for statistical analysis.

\section{RESULTS}

The seedlings of Myrocarpus frondosus showed differences in growth in relation to degree of shading. There was an interaction $(\mathrm{p}<0.05)$ between the factors (shading $\times$ time) for the height $(\mathrm{H})$, stem diameter $(\mathrm{SD})$, and $\mathrm{H} / \mathrm{SD}$ ratio. For $\mathrm{H}$, the growth linearly increased in treatments with $0 \%$ (full sun) and $30 \%$ shading, and quadratic growth occurred with $50 \%$ and $70 \%$ shading (Figure 2A).
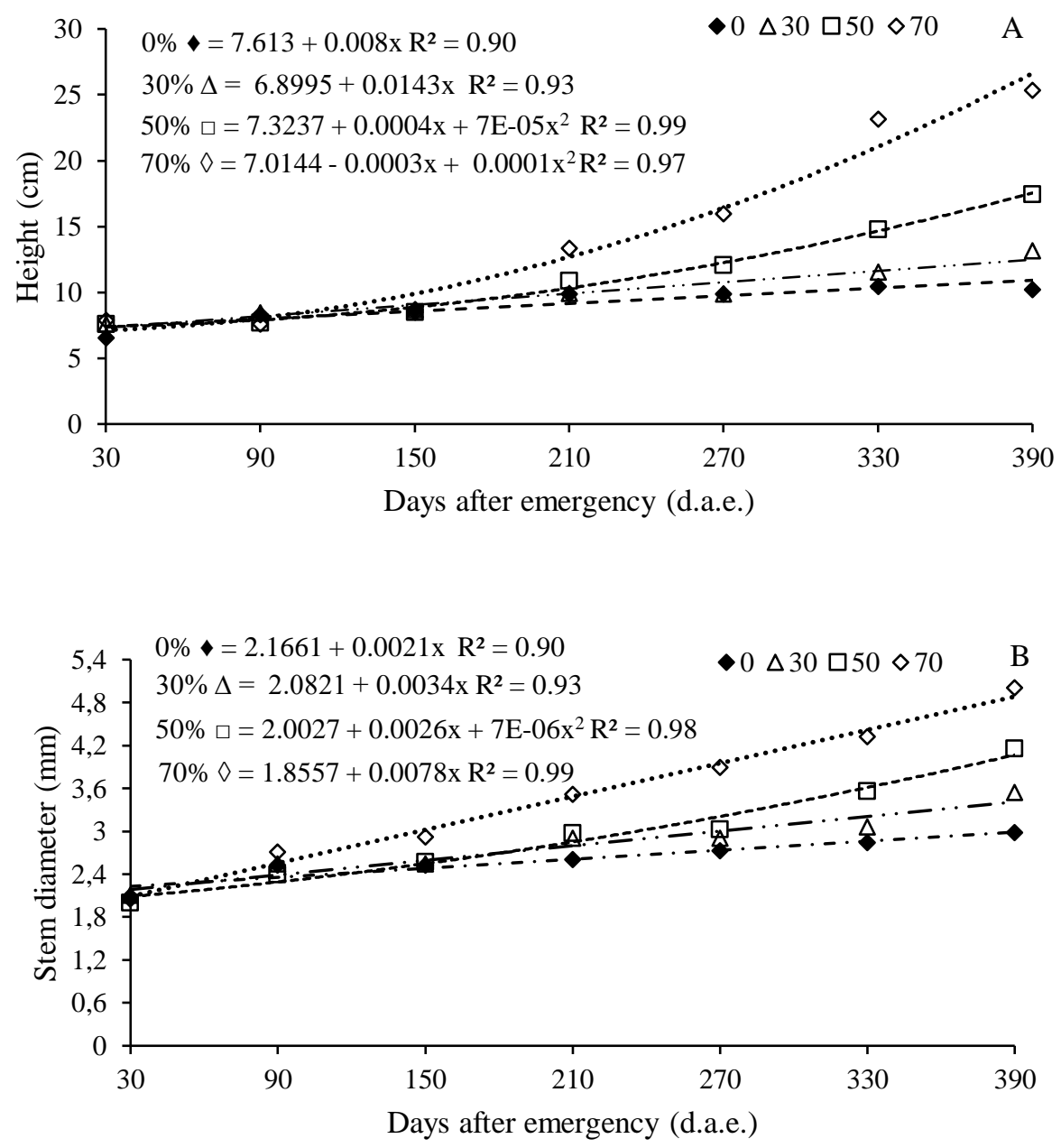

FLORESTA, Curitiba, PR, v. 51, n. 1, p. 137-145, jan/mar 2021.

Aimi, S. C. et.al. 


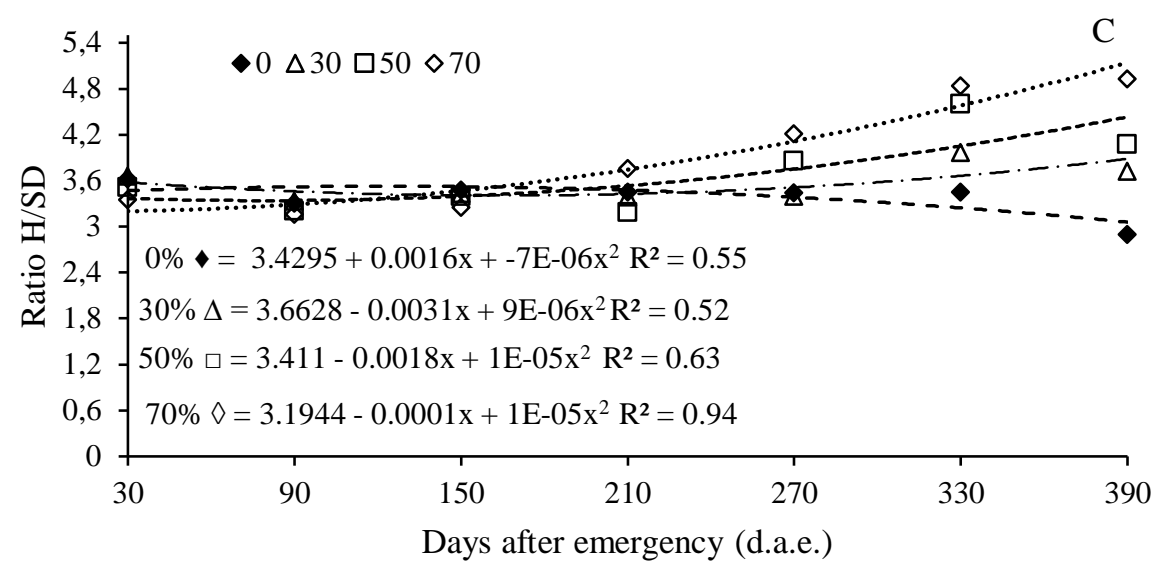

Figure 2. Height (A), stem diameter (B) and H/SD ratio (C) of Myrocarpus frondosus seedlings at different shading and evaluation times in a nursery in Santa Maria, RS.

Figura 2. Altura (A), diâmetro do coleto (B) e relação H/DC (C) de mudas de Myrocarpus frondosus em função de diferentes sombreamentos e tempos de avaliação, em viveiro, Santa Maria, RS.

For the SD, only the 50\% shading level showed increasing quadratic growth; in the other treatments, the growth increased linearly. For both $\mathrm{H}$ and SD, the highest averages were observed in $70 \%$ shade and the lowest in full sun (Figure 2B). For the H/SD ratio, plants in 30, 50, and 70\% shade showed increasing quadratic growth, while full sun treatment showed a decreasing H/SD ratio (Figure 2C).

There was a significant effect of shading $(\mathrm{p}<0.05)$ on aerial dry matter $(\mathrm{ADM})$, root dry matter $(\mathrm{RDM})$, total dry matter (TDM), Dickson quality index (DQI), root volume (RV), area leaf (AL), and root length (RL) (Table 1). For the attributes ADM, RDM, TDM, DQI, RV, and AL, the highest averages were observed with $70 \%$ shading and the lowest in full sun (Table 1). For the RL, the highest averages were obtained with either $70 \%$ or $50 \%$ shading.

Table 1. Aerial dry matter (ADM), root dry matter (RDM), total dry matter (TDM), Dickson quality index (DQI), root volume (RV), leaf area (LA) and root length (RL), at 390 days after the emergence of Myrocarpus frondosus seedlings in a nursery in Santa Maria, RS.

Tabela 1. Matéria seca aérea (MSA), matéria seca radicular (MSR), matéria seca total (MST), índice de qualidade de Dickson (IQD), volume radicular (VR), área foliar (AF) e comprimento radicular (CR), aos 390 dias após a emergência de mudas de Myrocarpus frondosus em viveiro, Santa Maria, RS.

\begin{tabular}{|c|c|c|c|c|c|c|c|}
\hline $\begin{array}{c}\text { Shading levels } \\
(\%)\end{array}$ & $\underset{(\mathrm{g})}{\mathbf{A D M}}$ & $\begin{array}{c}\text { RDM } \\
(\mathrm{g})\end{array}$ & $\begin{array}{c}\text { TDM } \\
(\mathrm{g})\end{array}$ & DQI & $\begin{array}{c}\text { RV } \\
(\mathbf{m L})\end{array}$ & $\begin{array}{c}\mathbf{L A} \\
\left(\mathbf{c m}^{2}\right)\end{array}$ & $\begin{array}{l}\text { RL } \\
(\mathbf{m})\end{array}$ \\
\hline 0 & $0.2564 c^{*}$ & $0.3049 \mathrm{c}$ & $0.5612 \mathrm{c}$ & $0.15 \mathrm{c}$ & $1.0 \mathrm{c}$ & $7.255 \mathrm{c}$ & $3.929 \mathrm{c}$ \\
\hline 30 & $0.3418 \mathrm{c}$ & $0.3296 \mathrm{c}$ & $0.6714 \mathrm{c}$ & $0.14 \mathrm{c}$ & $1.1 \mathrm{c}$ & $20.015 \mathrm{~b}$ & $6.390 \mathrm{~b}$ \\
\hline 50 & $0.6171 \mathrm{~b}$ & $0.5914 \mathrm{~b}$ & $1.2085 \mathrm{~b}$ & $0.24 \mathrm{~b}$ & $2.3 \mathrm{~b}$ & $45.552 \mathrm{~b}$ & $7.451 \mathrm{ab}$ \\
\hline 70 & $1.6170 \mathrm{a}$ & $1.0611 \mathrm{a}$ & $2.6781 \mathrm{a}$ & $0.41 \mathrm{a}$ & $3.5 \mathrm{a}$ & $171.772 \mathrm{a}$ & $13.505 \mathrm{a}$ \\
\hline Mean & 0.7218 & 0.5848 & 1.3067 & 0.24 & 2.0 & 61.149 & 7.819 \\
\hline $\mathrm{CV}(\%)$ & 16.94 & 27.61 & 16.64 & 19.17 & 23.45 & 13.70 & 13.95 \\
\hline
\end{tabular}

${ }^{*}$ Means followed by the same letter do not differ by Tukey's test at $5 \%$ probability of error. CV: Coefficient of variation

For chlorophyll $a$, the highest averages were observed with $70 \%$ and $50 \%$ shade, with the lowest average being observed in plants kept in full sun. Chlorophyll $b$ also showed the highest average for seedlings with $70 \%$ shade and the lowest for plants in full sun (Table 2). For the chlorophyll $a / b$ ratio, the highest average was observed

FLORESTA, Curitiba, PR, v. 51, n. 1, p. 137-145, jan/mar 2021.

Aimi, S. C. et.al.

ISSN eletrônico 1982-4688

DOI: $10.5380 /$ rf.v51 i1. 67548 
with $0 \%$ (full sun), 30\% shade and 50\% shade. Carotenoids were found in greater quantity in seedlings with $70 \%$ shade, and treatments with $30 \%$ and $50 \%$ shade.

Table 2. Chlorophyll $a$, chlorophyll $b$, Chl $a / b$ ratio and carotenoids, at 390 days after emergence of Myrocarpus frondosus seedlings in a nursery in Santa Maria, RS.

Tabela 2. Clorofila $a$, clorofila $b$, relação clorofila $a$ /clorofila $b$ e carotenoides, aos 390 dias após emergência de mudas de Myrocarpus frondosus, em viveiro, Santa Maria, RS.

\begin{tabular}{ccccc}
\hline Shading levels (\%) & $\begin{array}{c}\text { Chlorophyll } \boldsymbol{a} \\
(\mathbf{m g ~ g ~ M F})\end{array}$ & $\begin{array}{c}\text { Chlorophyll } \boldsymbol{b} \\
\left(\mathbf{m g ~ g ~ M F} \mathbf{~ M F}^{-1}\right)\end{array}$ & Ratio $\boldsymbol{a} / \boldsymbol{b}$ & $\begin{array}{c}\text { Carotenoids } \\
\left(\mathbf{m g ~ g ~ M F}^{-1}\right)\end{array}$ \\
\hline 0 & $0.7294 \mathrm{c}^{*}$ & $0.1635 \mathrm{~b}$ & $4.6773 \mathrm{a}$ & $0.2662 \mathrm{~b}$ \\
30 & $1.0387 \mathrm{bc}$ & $0.2509 \mathrm{~b}$ & $4.2377 \mathrm{a}$ & $0.3431 \mathrm{ab}$ \\
50 & $1.3871 \mathrm{ab}$ & $0.3767 \mathrm{~b}$ & $3.8315 \mathrm{a}$ & $0.4115 \mathrm{ab}$ \\
70 & $1.7157 \mathrm{a}$ & $0.8338 \mathrm{a}$ & $2.1618 \mathrm{~b}$ & $0.4856 \mathrm{a}$ \\
\hline Mean & 1.2178 & 0.4062 & 3.7271 & 0.3766 \\
CV $(\%)$ & 17.16 & 36.71 & 15.03 & 17.30 \\
\hline
\end{tabular}

*Averages followed by the same letter do not differ by Tukey's test at 5\% probability of error. CV: Coefficient of variation

For the maximum quantum yield of PSII $\left(\mathrm{F}_{\mathrm{v}} / \mathrm{F}_{\mathrm{m}}\right)$ and electron transport rate $(\mathrm{ETR})$ there was a significant difference $(\mathrm{p}<0.05)$ between the shading. The maximum quantum yield of PSII $\left(\mathrm{F}_{\mathrm{v}} / \mathrm{F}_{\mathrm{m}}\right)$ was higher in plants with $70 \%$ shade, differing from other treatments, with the lowest average observed in seedlings in full sun. For ETR, the highest average was observed in plants with 50\% shade, with seedlings at $30 \%$ and $70 \%$ shade not significantly different (Table 3).

Table 3. Maximum quantum yield PSII $\left(\mathrm{F}_{\mathrm{v}} / \mathrm{F}_{\mathrm{m}}\right)$ and electron transport rate (ETR) of Myrocarpus frondosus seedlings in different shades, at 390 days after emergence in a nursery in Santa Maria, RS.

Tabela 3. Rendimento quântico máximo PSII $\left(\mathrm{F}_{\mathrm{v}} / \mathrm{F}_{\mathrm{m}}\right)$ e taxa de transporte de elétrons de mudas de Myrocarpus frondosus em diferentes sombreamentos, aos 390 dias após a emergência, em viveiro, Santa Maria, RS.

\begin{tabular}{|c|c|c|}
\hline Shading levels (\%) & $\mathbf{F}_{\mathbf{v}} / \mathbf{F}_{\mathbf{m}}$ & 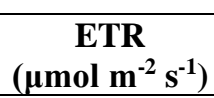 \\
\hline 0 & $0.37 \mathrm{~b}^{*}$ & $113.35 \mathrm{~b}$ \\
\hline 30 & $0.41 \mathrm{~b}$ & $198.87 \mathrm{ab}$ \\
\hline 50 & $0.43 \mathrm{~b}$ & $227.95 \mathrm{a}$ \\
\hline 70 & $0.60 \mathrm{a}$ & $206.76 \mathrm{ab}$ \\
\hline $\begin{array}{c}\text { Mean } \\
\text { CV }(\%)\end{array}$ & $\begin{array}{c}0.45 \\
19.98\end{array}$ & $\begin{array}{c}186.73 \\
25.50\end{array}$ \\
\hline
\end{tabular}

*Averages followed by the same letter do not differ by Tukey's test at 5\% probability of error. CV: Coefficient of variation

In the nursery, the shading levels influenced most of the morphological and physiological attributes of the Myrocarpus frondosus seedlings. The height and diameter of the collection in $70 \%$ shade were higher, indicating that this condition is suitable for the growth of the seedlings of this species (Figure 2).

\section{DISCUSSION}

The greatest growth in height in plants with $70 \%$ shading occurs in response to the greater investment in cell elongation, due to the strategy of plants to seek light (MOTA et al., 2012). On the other hand, in the cabreúva seedlings in full sun, light was not a limiting factor, and therefore they did not require a greater investment in plant height. In addition, in plants exposed to full sun, there may have been an increase in temperature in the leaves, intensifying the respiratory rate and reducing carbon fixation (TAIZ et al., 2017), which can be seen in the morphological attributes ADM, RDM, and TDM (Table 1). It was observed that the treatment in full sun was limiting for the growth of seedlings.

Some forest species, when subjected to shading, show greater growth in $\mathrm{H}$ and less investment in SD as a strategy to search for light (MOTA et al., 2012). However, for the cabreúva seedlings, the averages of the H/SD ratio indicate that there was no etiolation, since the greater investment in growth in height did not compromise the allocation of carbon for increasing the SD and other variables such as root length and root dry matter (Table 1).

FLORESTA, Curitiba, PR, v. 51, n. 1, p. 137-145, jan/mar 2021.

Aimi, S. C. et.al.

ISSN eletrônico 1982-4688

DOI: $10.5380 /$ rf.v51 i1. 67548 
For field planting, it is important to observe this relationship, as seedlings that have a higher H/SD are more susceptible to tipping and damage caused by wind, drought, and frost (RITCHIE et al., 2010). Considering that the cabreúva seedlings presented an average H/SD ratio of 4.93 at 390 d.a.e. with $70 \%$ shading, it is important to acclimatize the seedlings to full sun before planting.

The root length was greater with $50 \%$ and $70 \%$ shade (Table 1), which is important for the quality of the seedlings, as according to Grossnickle (2012), plants with a well-developed root system have greater capacity for survival and growth in the field under adverse conditions than those with lower RL. In addition, 70\% shading was also favorable for the greater accumulation of dry matter, resulting in more vigorous plants, which contradicts reports in the literature showing that in environments with low light intensity, plants tend to allocate more biomass to the leaves than the roots (POORTER et al., 2012) in an attempt to absorb a greater amount of light radiation. This response in the root growth of the cabreúva seedlings is interesting, since the plants invested in greater shoot biomass without reducing the root growth, ensuring a harmonious growth between shoot and roots.

The leaf area was associated with the levels of chlorophyll and carotenoids, which also showed higher values under $70 \%$ and $50 \%$ shading (Table 1). These results indicate that the seedlings have a greater capacity to absorb light energy, which was used in later photochemical reactions, contributing to the increase in photosynthetic capacity and, consequently, to greater growth in height and stem diameter. Lima et al. (2010) found higher amounts of chlorophyll $a$ in the leaves of Hymenaea courbaril with 50\% and 70\% shading, compared to leaves with $30 \%$ shading or in full sun, and the degree of chlorophyll $b$ decreased in plants in full sun, causing a greater chlorophyll ratio $a / b$. This behavior was also observed for the cabreúva seedlings in this study.

The leaf is an organ sensitive to changes in the environment and is characterized by presenting variability and plasticity (LARCHER, 2000). Full sun exposure caused a reduction in the leaf area in relation to the other treatments, which was described by Larcher (2000) as a strategy to decrease the transpiration rate, due to the smaller evaporation surface. For plants with $70 \%$ shading, the averages were higher. This fact can be explained by the capacity of plants to expand the leaf blade to increase light uptake (LARCHER, 2000). This response may imply greater vulnerability to water deficiency (JONES; MCLEOD, 1990). The leaf area is usually larger in more shaded environments than in full sun (LARCHER, 2000). It is important to know how plants respond and adapt to stressful conditions, such as the availability of light.

The results of photosynthetic pigment analyses were that plants develop different strategies to increase their efficiency in the use of diffuse radiation in shade and protect themselves against photo-oxidation in environments with greater light intensity. For the maximum quantum yield of PSII $\left(\mathrm{F}_{\mathrm{v}} / \mathrm{F}_{\mathrm{m}}\right)$, the low availability of light was not limiting for photosynthesis in seedlings. This result is directly related to the content of photosynthetic pigments in the leaves (Table 2). Cabreúva plants with $70 \%$ shading showed efficiency in the capture and use of light, which can be proven through the other morphological attributes evaluated, since in the condition of greater stress (full sun), this relationship decreased, indicating the damage to photosystem II. The electron transport rate (ETR) was higher in 50\% and 70\% shade and lower in full sun. This decrease in the value of ETR represents a reduction in the activity of photosystem II. Exposure to high irradiance can be harmful for some plants, as they absorb more photons of light than they can use, which can result in photoinhibition (ADAMS; ADAMS, 2006). Thus, the susceptibility to photoinhibition and the ability of the leaves to adapt to the increase in luminosity play an important role in energy production, growth, and photosynthetic competition among plants in more shaded places such as the understory (TAIZ et al., 2017). However, when shaded, the milder microclimate guarantees a lower leaf temperature and a lower transpiration rate, which may allow for a greater allocation of carbon to increase the leaf surface, improving the absorption of light in regions with less sun exposure.

The $50 \%$ and $70 \%$ shade conditions promoted changes in the morphophysiological attributes of the cabreúva seedlings, demonstrating that the species is tolerant to shaded environments, which was the ideal condition for its growth and development in the nursery. Thus, the control of luminosity with shade screens allows the production of quality seedlings, ensuring greater survival and initial growth in the field. This species would be useful in agroforestry systems (SAFs) and undergrowth enrichment plantations, such as in forest areas with low species diversity, and also in consortium with other species, or as a secondary species, in projects aimed at recovering altered areas.

\section{CONCLUSION}

- The growth and development of the Myrocarpus frondosus seedlings can be reduced when they are exposed to full sun. This species needs shading in the initial phase of its growth, with $50 \%$ and $70 \%$ shading as ideal alternatives for seedling production in the nursery.

FLORESTA, Curitiba, PR, v. 51, n. 1, p. 137-145, jan/mar 2021.

Aimi, S. C. et.al.

ISSN eletrônico 1982-4688

DOI: $10.5380 /$ rf.v51 i1. 67548 


\section{ACKNOWLEDGMENTS}

The authors would like to thank Coordenação de Aperfeiçoamento de Pessoal de Nível Superior (CAPES) for granting a scholarship to the first author, and to the Conselho Nacional de Desenvolvimento Científico e Tecnológico (CNPq) for the scholarship of productivity in research provided to the second author.

\section{REFERENCES}

ALVARES, C. A.; STAPE, J. L.; SENTElHAS, P. C.; GONÇALVES, J. L. M.; SPAROVEK, G. Köppen’s climate classification map for Brazil. Meteorologische Zeitschrift, Germany, v. 22, n. 6, p. 711-728, 2013.

ARAUJO, M. M.; NAVROSKI, M. C.; SCHORN, L. A.; TABALDI, L. A.; RORATO, D. G.; TURCHETTO, F.; ZAVISTANOVICZ, T. C.; BERGHETTI, A. L. P.; AIMI, S. C.; TONETTO, T. S.; GASPARIN, E.; KELLING, M. B.; AVILA, A. L.; DUTRA, A. F.; MEZZOMO, J. C.; GOMES, D. R.; GRIEBELER, A. M.; SILVA, M. R.; BARBOSA, F. M.; LIMA, M. S. Caracterização e análise de atributos morfológicos e fisiológicos indicadores da qualidade de mudas em viveiro florestal. In: ARAUJO, M. M; NAVROSKI, M. C.; SCHORN, L. A. (Org.). Produção de sementes e mudas: um enfoque à silvicultura. Santa Maria: Editora UFSM, v. 1, 2018, p. 345366.

BRANCALION, P. H. S.; CHAZDON, R. L. Beyond hectares: four principles to guide reforestation in the context of tropical forest and landscape restoration. Restoration Ecology, Washington, v. 25, n. 4, p. 491-496, 2017.

CARVALHO, P. E. R. Espécies Arbóreas Brasileiras. Brasília: EMBRAPA Informação Tecnológica. Colombo, PR: EMBRAPA Florestas, v. 1, 2003, 1039 p.

DICKSON, A.; LEAF, A. L.; HOSNER, J. F. Quality appraisal of white spruce and white pine seedling stock in nurseries. Forestry Chronicle, Ottawa, v.36, n.8, p.10-13, 1960.

DEMMIG-ADAMS, B.; ADAMS, W. W. Photoprotection in an ecological context: the remarkable complexity of thermal energy dissipation. New Phytologist, Cambridge, v. 172, p. 11-21, 2006.

EQUIPE ESTATCAMP. Software Action. Estatcamp - Consultoria em estatística e qualidade, São Carlos - SP, Brasil. 2014.

FERREIRA, D. F. Sisvar: a Guide for its Bootstrap procedures in multiple comparisons. Ciência e Agrotecnologia. Lavras, v. 38, n. 2, p. 109-112, 2014.

GONÇALVES, J. L. M. et al. Produção de mudas de espécies nativas: substrato, nutrição, sombreamento e fertilização. In: GONÇALVES, J. L. M.; BENEDETTI, V. (Eds.). Nutrição e fertilização florestal. Piracicaba: IPEF, 2005. p. 309-350.

GRINGS, M.; BRACK, P. Árvores da vegetação nativa de Nova Petrópolis, Rio Grande do Sul. Iheringia, Porto Alegre, v. 64, n. 1, p. 5-22, 2009.

GROSSNICKLE, S. C. Why seedlings survive: influence of plant attributes. New Forests, Netherlands, v. 43, p. $711-738,2012$

HISCOX, J. D.; ISRAELSTAM, G. F. A method for the extraction of chlorophyll from leaf tissue without maceration. Canadian Journal of Botany, Ottawa, v. 57, p. 1332-1334, 1979.

JONES, R. H.; MCLEOD, K. W. Growth and photosynthetic responses to a range of light environments in Chinese tallow tree and Carolina ash seedlings. Forest Science, Bethesda, v. 36, p. 851-862, 1990.

LARCHER, W. Ecofisiologia Vegetal. São Carlos: RiMa, 2000, 531 p.

LICHTENTHALER, H. K. Chlorophylls and carotenoids: pigments of photosynthetic biomembranes. Enzymol Methods in Enzymology, New York, v. 148, p. 350-382, 1987.

LIMA, A. L. DA S.; ZANELLA, F.; CASTRO, L. D. M. de. Crescimento de Hymenaea courbaril L. var. stilbocarpa (Hayne) Lee et Lang. e Enterolobium contortisiliquum (Vell.) Morong (Leguminosae) sob diferentes níveis de sombreamento. Acta Amazônica, Manaus, v. 40, n. 1, p. 43-48, 2010.

MISSOURI BOTANICAL GARDEN (MOBOT). Explore the beta release of web TROPICOS. Disponível em: http://www.tropicos.org/>. Acesso em: 30 abr. 2019.

POORTER, H. et al. Biomass allocation to leaves, stems and roots: meta-analyyses of interspecific and environmental control. New Phytologist, Cambridge, v. 193, n. 1, p. 30-50, 2012. 
RITCHIE, G. A.; LANDIS, T. D.; DUMROESE, R. K. Assessing plant quality. In: LANDIS, T. D.; DUMROESE, R. K.; HAASE, D. L. Seedling Processing, Storage, and Outplanting. v. 7, Washington, DC: U.S. Department of Agriculture Forest Service, 2010, cap.2, p 19-81.

REIS, S. M.; MARIMON-JÚNIOR, B. H.; MORANDI, P. S.; OLIVEIRA-SANTOS, C.; OLIVEIRA, B. DE; MARIMON, B. S. Desenvolvimento inicial e qualidade de mudas de Copaifera langsdorffii Desf. sob diferentes níveis de sombreamento. Ciência Florestal, Santa Maria, v. 26, n. 1, p. 11-20, 2016.

SANTI, I. I.; GATTO, D. A.; MACHADO, M. R. G.; SANTOS, P. S. B.; FREITAG, R. A. Chemical Composition, Antioxidant and Antimi- crobial Activity of the Oil and Plant Extract Myrocarpus frondosus Allemão. American Journal of Plant Sciences, Estados Unidos, v. 8, p. 1560-1571, 2017.

SANCHES, M. C.; MARZINEK, J.; BRAGIOLA, N. G.; TERRA NASCIMENTO, A. R. Morpho-physiological responses in Cedrela fissilis Vell. submitted to changes in natural light conditions: implications for biomass accumulation. Trees, Berlin, v. 31, p. 215-227, 2017.

STEFFEN, W.; RICHARDSON, K.; ROCKSTRÖM, J.; CORNELL, S.; FETZER, I.; BENNETT, E.; BIGGS, R.; CARPENTER, S.; VRIES, W.; WIT, C.; FOLKE, C.; GERTEN, D.; HEINKE, J.; MACE, G.; PERSSON, L.; RAMANATHAN, V.; REYERS, B.; SÖRLIN, S. Planetary boundaries: guiding human development on a changing planet. Science, Washington, v. 347, p. 1-12, 2015.

TAIZ, L.; ZEIGER, E.; MOLLER, I.; MURPHY, A. Fisiologia e desenvolvimento vegetal. 6.ed. Porto Alegre: Artmed, 2017, 888 p. 